\title{
IMPACT OF COVID-19 ON RETAIL BUSINESS MODELS AND CONSUMER SENTIMENTS OF INDIA
}

\author{
Sarvagya Malik \\ Amity International School Noida \\ DOI: 10.46609/IJSSER.2021.v06i07.039 URL: https://doi.org/10.46609/IJSSER.2021.v06i07.039
}

\begin{abstract}
Covid-19 has changed the perspective of human beings in many ways. It has led to difficult macroeconomic outcomes and a major change in consumer expectations and retail business operations. India declared complete lockdown of the nation and the shutting down of the economy led to non-availability of many goods and services. The country saw a sizeable impact on the retail industry and consumer sentiments due to the economic instability. This article looks at the impact of the pandemic on retail business models and consumer behaviour during the crisis.
\end{abstract}

\section{Objective}

The main purpose of this research paper is to understand the impact of covid on retail consumers behaviour and business models through qualitative as well as quantitative analysis.

\section{Literature review}

\subsection{Introduction}

The COVID-19 pandemic is disrupting the functioning of economies around the globe. The pandemic has slowed down the overall growth of sectors causing fluctuations in demand, supply and inventory management. The virus has forced the consumers to self-quarantine and rely entirely on E- commerce. It has been difficult for the retail industry in India to regain their customers due to the negative impact on the supply chain. Consumers are changing their buying habits due to an impact on their disposable income. The retail industry is rapidly investing in digitalization in order to cope up with changing business environment. In the initial days of the pandemic several retail businesses tried to satisfy their customer's needs by adapting direct to consumer model but they failed to cope up with the burst in demand. This led to delayed deliveries and tremendous decline in customer satisfaction. Health and safety concerns among the masses has compelled them to adapt contactless payment options. The pandemic has 


\section{International Journal of Social Science and Economic Research}

ISSN: $2455-8834$

Volume:06, Issue:07 "July 2021"

instigated panic buying and reduced the willingness of the consumers to go out and shop. It is important for the retail industry to understand [1] the decline in the customer buying confidence [2] staff shortages and [3] supply chain restrictions. In India the retail industry is offering personalized experiences to customers at a high pace to increase personal experiences and loyalty. During the pandemic, people are spending less income on items perceived as luxury or non-essential (such as clothing, shoes, make-up, jewellery, games and electronics).

The traditional low cost retailing includes the local kirana shops, general stores, single owner manned medical stores and restaurants. These form the core of trade in the retail industry. These businesses are successful in managing their inventory and running a profitable venture without any external funding. They stores provide an excellent customer service through customizable and personalized service to their customers. Although these retailers lack man power they utilize their resources in the most convenient and profitable way and have discovered a way to survive economic downfalls and changing customer demands. Customers prefer small scale stores which are available in their neighbourhoods because they have developed a certain trust in them. This trust plays an important role in the buying behaviour of the customers. The unorganized retailers have offered a fast delivery system and a no questions asked return policy for several decades. They have also implemented all the economic and management principles in their businesses without any prior knowledge. Such factors have put them a step ahead of the large organizations which are entering the market. Being customer centric and to be able to earn profits has given these retailers a strong position in the market. Unorganized retailers also face many threats from E-commerce and D2C businesses. They have tried to adapt to the modern technologies to some extent, they now take home deliveries and provide special offers to their customers but a lot more has to be done to cater to the rising customer demands. They have realized the impact that technology brings to their business and looking for new and innovative ways to cope up with the large industry giants.

Domestic and multinational corporations have entered the retail industry in India. This has led to rising concerns that they will disrupt the traditional small scale businesses. These MNC's have a strong supply chain which reduces the number of middlemen when compared to the unorganized sector. Changing demographic profile and increasing disposable incomes are the key factors that are leading to the growth of organized retailing. In India the number of middle class consumers are rising which has provided a golden opportunity for modern retailers to grow their businesses. Technology is one of the strong factors responsible for the growth of organized retailing. Computerization and IoT have revolutionized the market. Bar code systems along with several innovations are contributing to optimum utilisation of the resources. 
International Journal of Social Science and Economic Research

ISSN: 2455-8834

Volume:06, Issue:07 "July 2021"

\subsection{Post covid environment}

The desire to break the chain of covid-19 transmission has led to an increase in online retail shopping. The new retail pricing strategies have taken a toll on customer experience. This has negatively impacted the market task scenarios which would permit customers to turn down on pricing. The shoppers now have an interest to understand the supply-chain of the product they purchase and to promote local stores. State wide lockdowns have pushed the employees from their company offices to their homes. Corporations have been compelled to spend money on telecom and e-commerce skills with a purpose to maintain the quality of their operations. Employees have created new ways to maximize their productivity at home. The pandemic has taught them that they don't have to be physically present in order to do certain tasks. Work from home has gone from a far-off possibility to a wonderful and productive experience. Market fluctuations and economic uncertainties have brought the attention of the general public towards long term goals of their families by putting aside discretionary desires. Most of the retail costs are fixed which is putting financial burden on retailers. The industry is facing liquidity challenges and large scale unemployment.

\section{The Composition Of India's Merchandise Retail Sector (all figures in US\$ Billion)}

\begin{tabular}{|c|c|c|c|c|}
\hline \multicolumn{5}{|c|}{ Split of Merchandise Spending in India } \\
\hline All values in US\$ Bn. & 2020 & 2022 & 2025 & $\begin{array}{c}\text { CAGR } \\
(2020-2025)\end{array}$ \\
\hline Food and Grocery & 545 & 660 & 850 & $10 \%$ \\
\hline Apparel and accessories & 64 & 78 & 104 & $10 \%$ \\
\hline Jewellery \& watches & 65 & 81 & 111 & $11 \%$ \\
\hline Consumer electronics & 53 & 65 & 91 & $12 \%$ \\
\hline Home \& living & 35 & 44 & 60 & $11 \%$ \\
\hline Pharmacy \& wellness & 24 & 31 & 42 & $11 \%$ \\
\hline Footwear & 10 & 13 & 18 & $11 \%$ \\
\hline Others & 26 & 31 & 39 & $8 \%$ \\
\hline Total & 822 & 1005 & 1315 & $10 \%$ \\
\hline
\end{tabular}

Fig. 1. The composition of India's merchandise retail sector 
International Journal of Social Science and Economic Research

ISSN: 2455-8834

Volume:06, Issue:07 "July 2021"

Size \& Split Of India's Private Spending On Services (US\$ Billion)

\begin{tabular}{|c|c|c|c|c|}
\hline \multicolumn{5}{|c|}{ Size sisplit of Private 5pending On Services } \\
\hline All values in USD tin, & 2020 & 2022 & 2025 & $\begin{array}{l}\text { CACR } \\
\text { (20202025) }\end{array}$ \\
\hline Education & 131 & 148 & 214 & $13.1 \%$ \\
\hline Hesithere services & 94 & 106 & 156 & $13.8 \%$ \\
\hline Comm \& Conectivity & 86 & 97 & 143 & $14 \%$ \\
\hline Peruonal Iratipartation & 84 & 95 & 137 & $13 \%$ \\
\hline Food senvices & 64 & 71 & 95 & $10 \%$ \\
\hline Tavel \& Lelsure & 52 & 56 & 75 & $10.1 \%$ \\
\hline Entertsiament & 29 & 32 & 47 & $13.8 \%$ \\
\hline $\begin{array}{l}\text { Small Savines, Housing } \\
\text { etc. }\end{array}$ & 467 & 515 & 718 & $11.7 \%$ \\
\hline Total: & 1006 & 1120 & 1585 & $12 \mathrm{x}$ \\
\hline
\end{tabular}

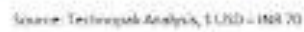

Fig. 2. Size and Split of India's private spending on Services

\section{India's Retail Channel Split}

Split of Total Retail Market Across Different Channels (US\$ Billion)

\begin{tabular}{|c|c|c|c|c|}
\hline & 2020 & 2022 & 2025 & $\begin{array}{c}\text { CAG } \\
\text { (20202025) }\end{array}$ \\
\hline Brick led Modern Retail & 58 & 85 & 150 & $21 \%$ \\
\hline E.Commerceled & 31 & 38 & 81 & $21 \%$ \\
\hline Total Modern Retail & 89 & 123 & 230 & $21 \%$ \\
\hline Iraditional Retail & 733 & 854 & 1084 & $8 \%$ \\
\hline Total & 822 & 1005 & 1315 & $10 \%$ \\
\hline
\end{tabular}

Soare: Techrepai Mnalpic, 1 USD sikn 70

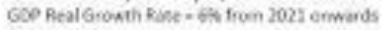

inflation $-2 x$

Fig. 3. Split of Total Retail Market Across Different Channels 
International Journal of Social Science and Economic Research

ISSN: 2455-8834

Volume:06, Issue:07 "July 2021"

The above tables (source: Technopak Analysis) indicate that more than $65 \%$ of the e-commerce activity comprises of mobile phones and other digital products and then to a lower extent, consumer durables and discretionary. The largest consumer spending in India is in food and grocery which is nearly $66 \%$. Covid-19 provoked lockdowns and gave a significant boost to online commerce.

\subsection{Challenges faced by retail outlets:}

\section{Disrupted supply chain}

In India there is a lack of efficient supply chain management. A strong supply chain is needed to bring down the inventory costs. This will help the businesses and the communities to manage and tackle short term crisis in order to cope up with the changing customer demands.

\section{Lack of technology adoption:}

Retailers need to adjust to the shifting customer experiences in order to survive from competition. It is essential for the retailers to utilize the right technology in order to scale. New technology should be strategically used to transform shopping experiences. Billing, payments, supply chain management, stock tracking and staff management softwares are essential the day to day operations.

III. Security and Risk management:

Social distancing has compelled the retailers to change their sales strategies and models to ensure social distancing measures. Adapting to thermo scanners and cameras in order increase security and reduce the transmission risk. Retailers need to manage their staff more efficiently.

IV. Fall in consumption:

There is a decrease in the consumption pattern of consumers which tends to fall even more during the next six to nine months. The lockdowns, new covid-19 variants, reduction in disposable income and fear of job security have decreased the buying confidence of the consumers.

V. Diminishing brand loyalty:

Companies which have spent a massive amount of time to build their customer loyalty are facing major problems due to the covid-19 restrictions. People are focussing less on their discretionary desires and more on essential items. Customers tend to purchase items from their nearby stores to meet their daily needs. Small retailers are selling more of private labelled items which has paved a way for consumers to switch from nationalized brands. 
VI. Economic recession: Due to the lockdowns the economy is facing a slow paced growth which is leading to shrinkage in business volumes. Overall financial condition of retailers is worsening.

\subsection{Adaptive actions for retailers to tackle the challenges:}

I. Reorganize the supply chain by partnering up with hyperlocal stores and vendors. Retailers need to manage the flow of essential items and re-plan their strategies regarding discretionary items.

II. Retailers need to re-evaluate their current product range and stock on hand. This will help them to evaluate demand patterns and forecasts.

III. Adopt a competitive pricing strategy and cost structure to ensure sales recovery. Invest in marketing and carry out targeted campaigns.

IV. Construct their relations with new suppliers and negotiate for post covid-19 operations.

V. Adjust store policies in order to ensure social distancing.

\subsection{Consumer behaviour approaches in times of crisis:}

The pandemic bought a large impact on the economy which has led to change in market dynamics. While purchases are currently concentrated on 'basic' needs, people are shopping more carefully by shifting more towards hyperlocal stores and e-commerce. To maintain safety consumers are using contactless payments. Offices are seeing an increase in virtual workforce but are still looking to cut costs. Consumers are making sure to limit the food waste and are largely inclined towards sustainable product options. The e-commerce sector is rapidly creating a positive user experience for the consumers as well as the retailers. There are several factors that have disrupted the consumption habits during the pandemic. 

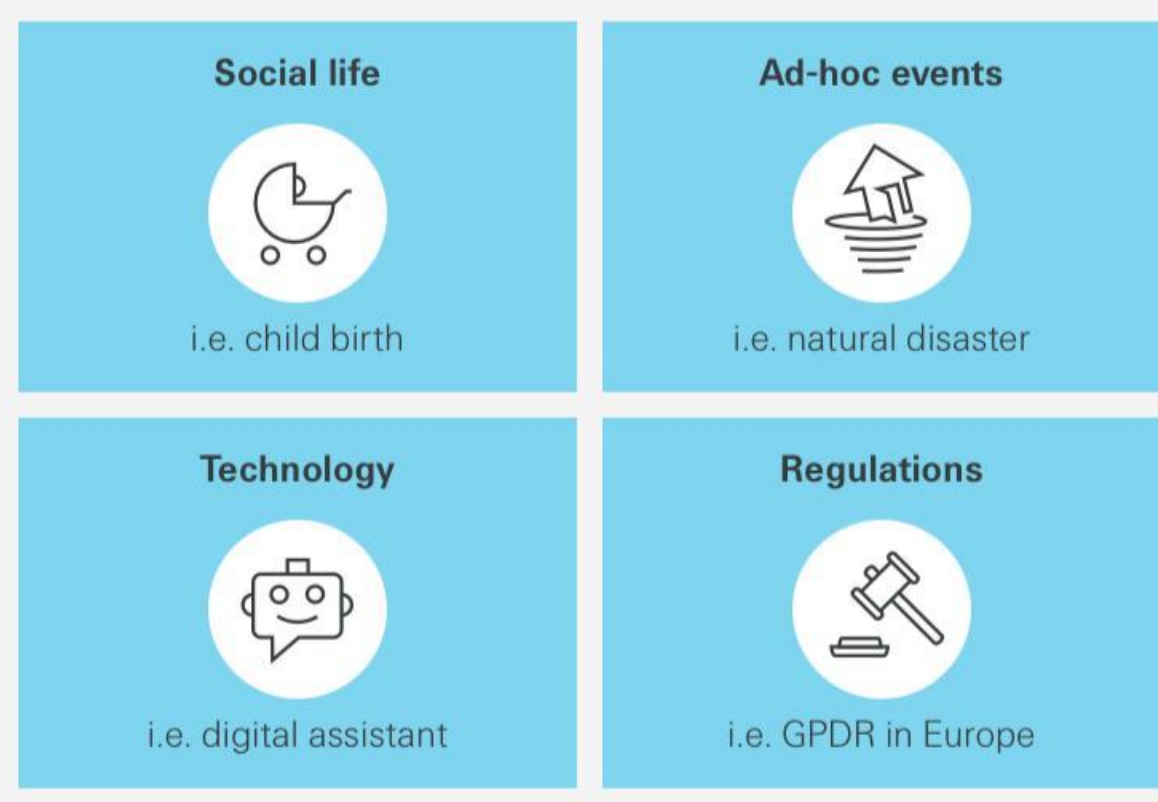

Source: Adapted from Jagdish Sheth, Journal of Business Research, 117 (2020), pp 280-283.

Fig. 4. Drivers of major change in consumption

Fig. 4. Depicts the drivers that are changing the consumer behaviour which includes several social life events such as marriage, childbirth etc. Technology also plays an important as a change driver as many business models have changes and brought Artificial Intelligence to drive the customers. The third is the new rules and regulations introduced by the governments such as solar and wind power generation. This has empowered the customers to adapt sustainability. Unexpected events such as earthquakes and the most recent pandemic are major drivers as well. 
Shift to value and essentials

\section{Consumer optimism has steadily increased since mid-May and has reached its highest levels since the start of the COVID-19 pandemic}

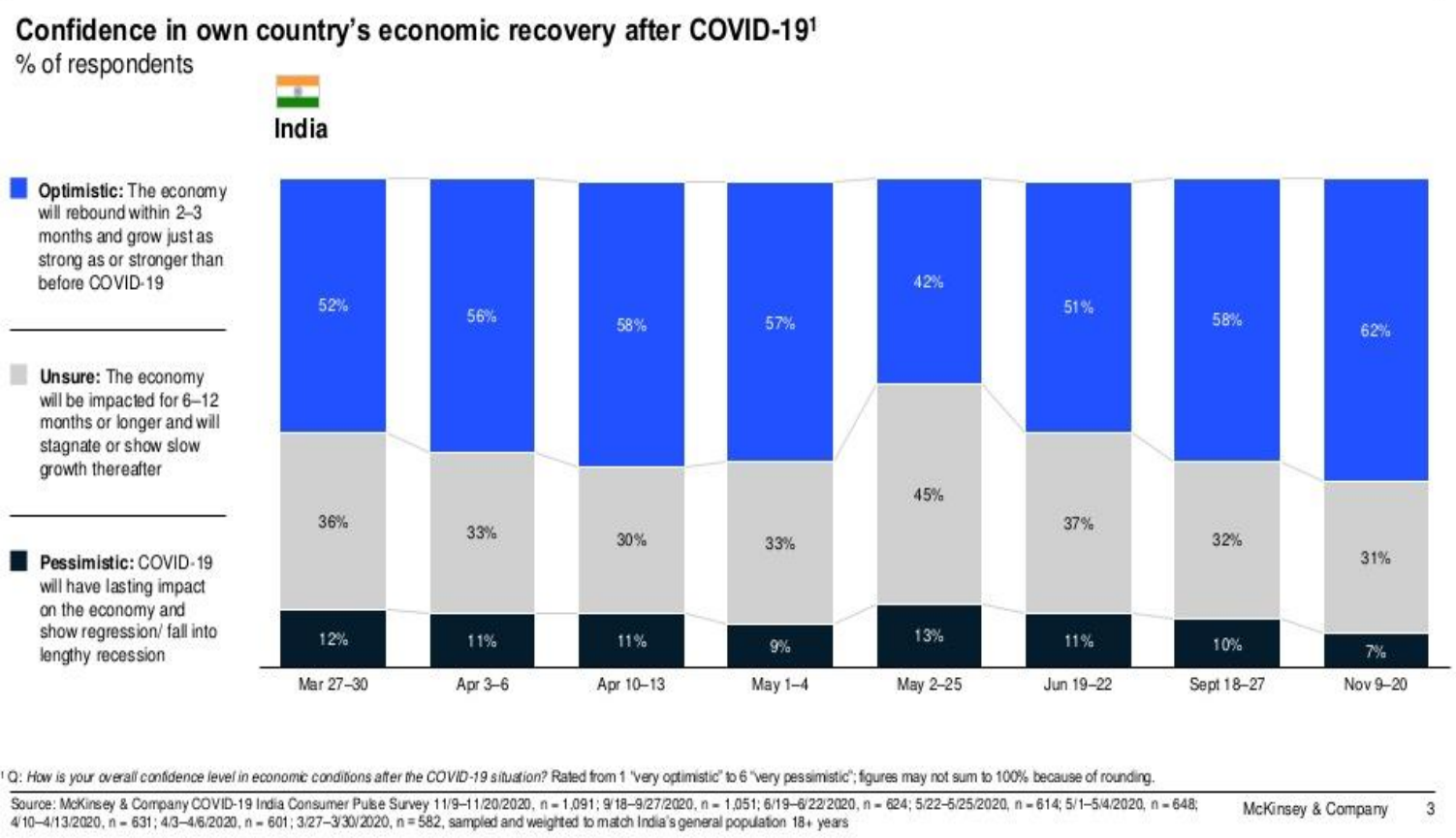

Fig. 5. Consumer confidence level regarding post covid economic recovery

( source: Consumer sentiment in India during the coronavirus crisis $\mid$ McKinsey ) 


\section{...with many consumers planning to shift almost completely online}

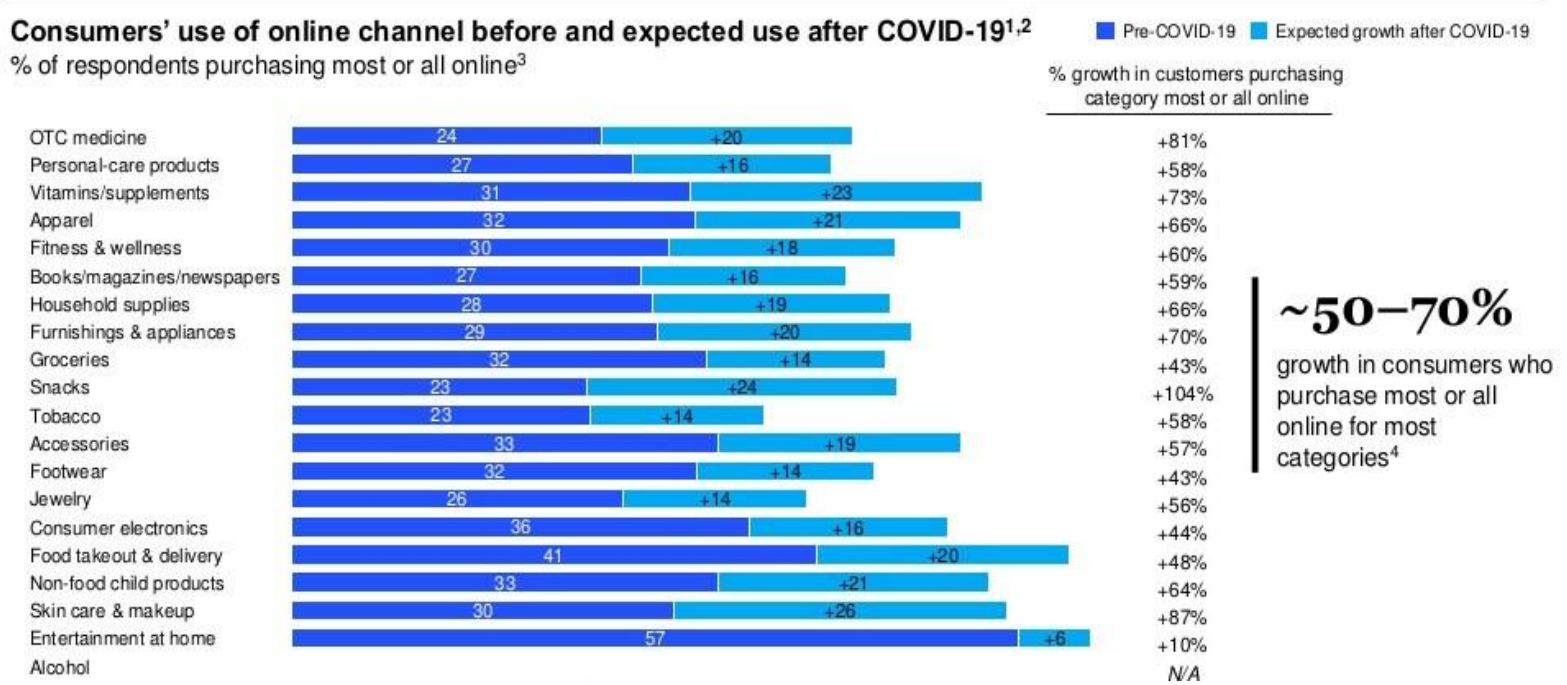

Fig. 6. Shift towards e-commerce pre and post covid

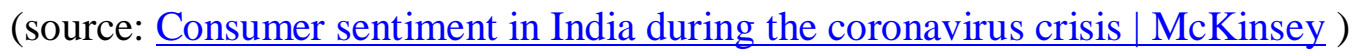

Shock to loyalty

\section{The majority of Indian consumers have tried a new shopping behavior and most intend to continue with it beyond the pandemic}

Have you used any of the following since COVID-19 started ${ }^{1}$

$\%$ of respondents

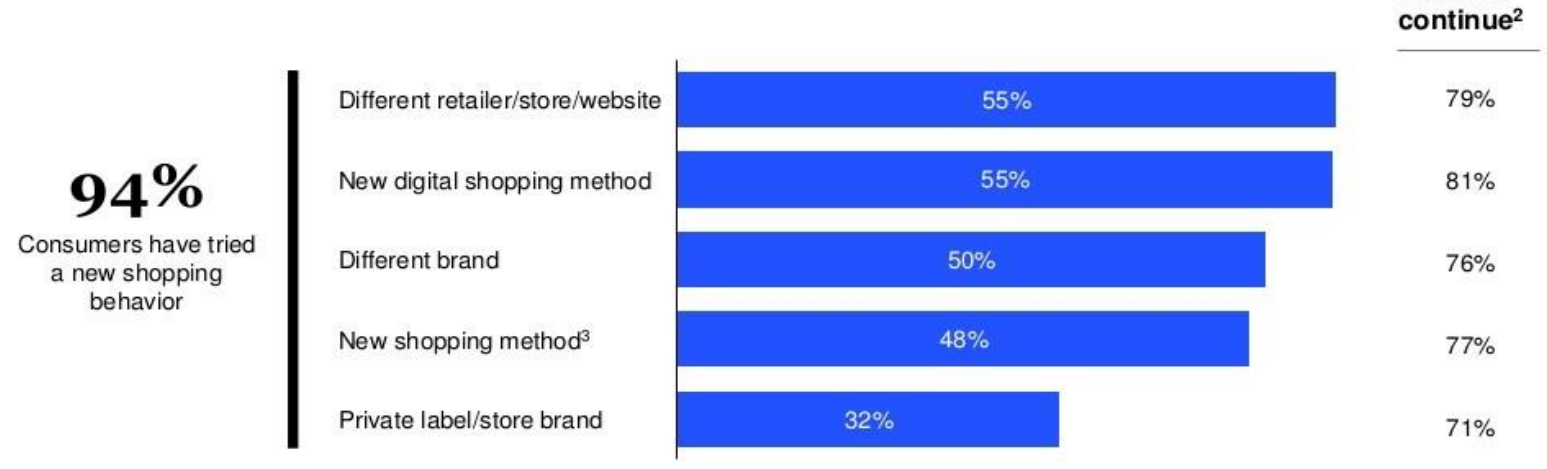

fig.7. Change in customer preferences and brand loyalty

(source: Consumer sentiment in India during the coronavirus crisis $\mid$ McKinsey ) 


\section{International Journal of Social Science and Economic Research}

ISSN: $2455-8834$

Volume:06, Issue:07 "July 2021"

\section{Conclusion}

The research shows that the consumers will focus more on health, hygiene and essential products in the near future. It is essential for the retail enterprises to switch from traditional methods to modern ones in order to survive the pandemic. It can be concluded that the consumer buying patterns will not be the same as before and the era of 'the new normal' has started. Retailers will need to manage the load of occupancy costs and rents in order to stand strong amid the pandemic. The pandemic has shifted many wealthy retailers from a positive to a negative cash flow and a depletion in working capital. The new consumer behaviour trends no longer align with their current business propositions and there is a constant search for alternatives. Innovative digital solutions will help the business owners to remain relevant and form a strong foundation for growth.

\section{References}

[1] $\quad$ https://www.accenture.com/ acnmedia/PDF-123/AccentureCOVID19-Pulse-SurveyResearch-PoV.pdf

[2] https://www2.deloitte.com/content/dam/Deloitte/in/Documents/consumer-business/inconsumer-impact-of-covid-19on-consumer-business-in-india-noexp.pdf

[3] https://www.mckinsey.com/business-functions/marketing-and-sales/our-insights/surveyindian-consumer-sentiment-during-the-coronavirus-crisis

[4] https://www.kantar.com/Campaigns/Covid-19-Barometer

[5] https://www.mckinsey.com/business-functions/marketing-and-sales/our-insights/surveyindian-consumer-sentiment-during-the-coronavirus-crisis

[6] https://reliefweb.int/report/world/world-risk-annual-report-global-preparedness-healthemergencies-global-preparedness

[7] Coronavirus impact on India's retail sector - The Economic Times (indiatimes.com)

[8] https://home.kpmg/content/dam/kpmg/in/pdf/2020/04/potential-impact-of-covid-19-on-theindian-economy.pdf

[9] https://www.assocham.org/upload/Recommendations-for-a-National-Response-to-theEconomic-Impact-of-Covid-19_Final.pdf

[10] https://www.mycii.in/KmResourceApplication/65567.COVID19PMOnote20Mar2020002.pd $\underline{\mathrm{f}}$ 